\title{
12. On Empty Spaces, Silence, and the Pause
}

\author{
Rebecca Amato
}

\begin{abstract}
Before there is an aesthetic of gentrification, there is disinvestment. In between both is the production - and perception - of empty space ready to be filled. The production of empty space has a long history in New York City, from settler colonialism to urban renewal to gentrification under the neoliberal regime of today. Techniques such as filtering, investing in the aesthetic potential of aging neighbourhoods, and declaring vacancy, have helped fuel the process of gentrification. More recently, that process has accelerated to insure New York's world city status by promising that every underutilized parcel will be filled with the tallest buildings, the greenest construction, and the densest use of land. Yet the city still has room for alternative visions that embrace a pause in the growth machine, such as cooperative centres and community gardens. These efforts, threatened though they are, provide models for inclusive cities where neoliberalism does not.
\end{abstract}

Keywords: vacancy, neoliberalism, brownstoners, colonialism, community garden, cooperative

Before there is an aesthetic of gentrification, there is disinvestment. In between both is the production - and perception - of empty space ready to be filled. In the context of the United States in the 196os and 1970s, images of disinvestment, reproduced in all manner of media, were dominated by cities cavernous with abandoned factories and apartment buildings, acres of overgrown weeds, rubble-strewn yards, and smouldering ruins. The press compared urban spaces, once densely populated, with war zones like Vietnam during American occupation and Dresden during World War II. Such tales gripped spectators with the tragedy of a hubristic, now-fading

Lindner, C. and G.F. Sandoval (eds), Aesthetics of Gentrification: Seductive Spaces and Exclusive Communities in the Neoliberal City. Amsterdam: Amsterdam University Press, 2021 DOI 10.5117/9789463722032_CH12 
civilization. They also served as the backdrop of gentrification and a precipitating agent for the rise of neoliberalism.

At the same time, the narrative of cities in decline overlooked two critical elements. First, disinvestment was and is produced by specific actors, such as the real estate industry, banks, speculators, investment trusts, federal policymakers, and city agencies, to devalue and deplete urban areas and their residents, only to spur growth when and where it is desirable to do so. It is not an accident of the land market, nor is it a naturally occurring phenomenon. In New York, municipal leaders actively disinvested in suffering neighbourhoods through strategies of what New York Senator Daniel Patrick Moynihan called "benign neglect" and New York City Housing Preservation and Development Commissioner Roger Starr labelled "planned shrinkage." Their arguments relied on the assertion that poor and minority populations were either architects of their own destruction or unjustified drains on public funds. By pulling back from the neighbourhoods in which these residents lived, the city not only stripped poor, usually Black and Latinx New Yorkers, of basic resources, it also colluded in producing empty spaces in the urban fabric, ready to be filled. This production of empty space as a catalyst for future growth has a long history in colonial projects and an elaborate present in the neoliberal era of gentrification, which I will explore below.

The other element that the narrative of cities in decline missed was the way in which claims of empty space and subsequent approaches to filling it were contested. Residents of abandoned New York neighbourhoods consistently worked to reclaim, repair, and cultivate the assets they still controlled through cooperative management and community self-help. They protested, often passionately, the loss of city services, but they did not wait for the city to do its job. Instead, when government failed, many New York neighbourhoods devised their own alternative systems of care, including gardening, construction training, and repair of crumbling buildings. These traditions endure even as what sociologist Harvey Molotch has called the "growth machine" churns out new ways of producing empty spaces. Here, I also look at two examples of cooperative management in New York City and consider the ways in which such efforts pause and disrupt not only neoliberalism, but also gentrification and its aesthetics.

\section{A View from the Harbor}

Before contemplating gentrification, it makes sense to trace New York City and its long-celebrated ethos of growth to its colonial origin story. 
After all, displacement and dispossession - two consequences of modernday gentrification - echo the kind of historical erasure that colonization delivered centuries before. Today, from a boat in the middle of New York harbour, hovering somewhere between estuary and ocean, one can see the dense towers of Manhattan nibble at the very edges of the island. But neither the density nor the island's edges existed in quite the same way at the moment of Dutch settlement in 1624. Jasper Danckaerts, a Dutch traveller and religious idealist, arrived in this same harbour in 1679, marvelling at the "bay swarm[ing] with fish, both large and small, whales, tunnies, and porpoises, whole schools of innumerable other fish" (Danckaerts 1913: 36). Danckaerts had come to New York seeking a suitable site to establish a utopian religious colony. His Labadist Christian faith, which promoted humility, the communal sharing of property, and manual labour, meant persecution back in the Netherlands. Once transported to the New World thanks in part to Danckaerts' scouting mission, the Labadists celebrated religious freedom only briefly, eventually dissolving their tiny settlements one by one. Even in 1679, however, Danckaerts was not the first utopian to see possible futures in the archipelago that would become New York and New Jersey - nor would he be the last. The harbour view kindled the imaginations of countless other immigrants arriving at Castle Clinton and later Ellis Island in the nineteenth and twentieth centuries. It inspired Walt Whitman to write of Manhattan in 1855 as if the harbour were its most notable feature: "City of hurried and sparkling waters! City of spires and masts! City nested in bays!" (Whitman 2009: 405). And it reassured the Rockefeller Brothers, David and Nelson, that Manhattan island was elastic enough to grow larger with landfill and that the powerful waters of the harbour could be tamed by slurry walls. Such affirmations gave Manhattan the World Trade Center and Battery Park City in the 1970s (Glanz and Lipton 2003).

But none of these dreams came without troubling reminders that these islands contained existing ways of life, nor, of course, were they limited to the harbour. And different utopians had different ways of reconciling what already existed. While Danckaerts might have celebrated the natural bounty of New York harbour and accepted that the skilled native peoples' "Sakemaker" (or sachem) was the same as his God, for the most part, newcomers to the area instead chose to make the extant social fabric disappear. This tradition has endured. The 1758 Treaty of Easton resulted in the final expulsion of the Lenni-Lenape from lands they had nourished for thousands of years (Kraft 1986). In 1853, the city's Common Council evicted 1,6oo predominantly African-, Irish-, and German-American working-class residents from the area that would become Central Park because, as the 
New-York Post reasoned, the new park promised "greater pecuniary benefits, direct and indirect ... and ever-enduring influence in adding to attractiveness and elevating the character of the metropolis, and thus fitting it for high destiny" (quoted in Rosenzweig and Blackmar 1998: 78). A hundred years later, Robert Moses, justifying creative destruction in a dense New York City, infamously declared, "You can draw any kind of picture you want on a clean slate and indulge your every whim in the wilderness in laying out a New Delhi, Canberra, or Brasilia, but when you operate in an overbuilt metropolis, you have to hack your way with a meat ax" (Caro 1974: 849). (Never mind that neither New Delhi, Canberra, nor Brasilia were built on unpeopled, "clean slates" either.)

It is perhaps a trick of colonial eyesight to filter out or vilify details like other human beings, natural and social ecosystems, and spiritual significance when it comes to a compelling opportunity to grow possible futures in a new land. But New York has rarely corrected this vision, nor has the city's propensity to exploit a problem with a gigantic spatial fix, whether it be social crisis or economic stagnation, strayed from an original impulse toward empire building. For those who clutter the current path of gentrification with demands to remain in their neighbourhoods, save their churches, live in homes they can afford, preserve their gardens, shop at the local grocery, or simply enjoy a trip on the ferry without having to work themselves to a pulp to afford urban life, the problem in New York is not the inability to grow possible futures. It is the failure to imagine a kind of growth that also includes them.

\section{Filtering}

To claim that gentrification is only another version of colonialism is perhaps cliché or, at the very least, heavy-handed. Yet, it is not difficult to see gentrification under the current neoliberal order as a kind of empire-building. In a 2013 New York Times op-ed, historian Kenneth T. Jackson argued that opposition to rezoning Manhattan's East Midtown for the construction of new skyscrapers was tantamount to threatening the city's status as "the financial, cultural, media, retailing, and fashion capital of not just the country but the world" (Jackson 2013). In New York, at least, neoliberalism produces an urban imaginary that promises that every underutilized parcel will be filled with the tallest buildings, the greenest construction, the most curated public spaces, and the densest use of every scrap of land available - that is, New York must dominate the global stage (Zukin et 
al. 1998; Cinar 2007; Greenberg 2008). At the same time, neoliberalism insures its command by making claims of scarcity that, it affirms, can only be solved through private investment and entrepreneurial ingenuity, and decelerated through new construction. If Manhattan's Hudson Yards or the slim, supertall towers of Midtown do not echo the empire of the past, neoliberalism tells us, then New York is finished. Pauses and silences are simply nostalgia. Displacement is simply a necessary filtering to meet the needs of global domination.

The term "filtering" has particular meaning in real estate. It refers to the process by which housing built for higher-income residents gradually depreciates to the extent that it becomes affordable to people with more modest incomes. In fact, much of the argument for rezoning New York City for the construction of taller, denser, more expensive residential towers is that increased residential supply will eventually filter down to those with lesser means. This suggests, of course, that the initial residents of new, high-end housing move on to presumably more attractive and salubrious surroundings so that their now-devalued property becomes available to new, less-wealthy consumers. In this way, filtering is understood as the natural way that private markets can produce low-income housing over time without directly building or investing in it. Put differently, filtering signifies the repositioning of a less-desirable product - that is, housing or a neighbourhood that has depreciated so much in value that it is no longer attractive to those with means - as one that is actually alluring to a new audience of consumers.

While filtering is very much part of the present-day discourse around affordable housing, the geographer Neil Smith also described the process back in 1979 when he published his influential essay, "Toward a Theory of Gentrification: A Back to the City Movement of Capital, Not People." From his perspective and historical context, the real purpose of filtering was not to provide housing to people with fewer resources, but rather to move capital from one urban, regional land market (the "inner-city") to another (the suburbs) to protect and grow return on investment. Moreover, Smith argued that the disparity between the under-valuation of "inner-city" land and its potential profitability, which he called the "rent gap," produced a scenario in which the return of capital to the inner-city through redevelopment became a fail-safe profit-generator. Land close to the city centre, which had been devalued, or filtered, through under-maintenance, block-busting, redlining, and landlord abandonment in the decades of suburbanization, did not lose its inherent worth simply because it had been leap-frogged. It was just banked until such time as values could rise again. The profit 
to be absorbed from this practice relied on the land itself - commodified and limited as it was. In other words, the filtering process then, as now, may have incidentally provided housing for people of lesser means, but its purpose was not to do so. Its purpose was to manipulate the land market so that wherever private investors moved their capital, they would avoid risk and their money would could continue to grow.

That Smith so keenly observed the ways agents such as banks, speculators, and the real estate industry fuelled this process in 1979 was prescient, not only because it foreshadowed the deep analysis of neoliberal governance that would later take root in the United States in the 1980s, but because the media image of cities was still one of decline and crisis. Despite the emergence of scholarship on gentrification that could be traced, famously, to sociologist Ruth Glass in London in 1964, American cities into the 1970 s were still battling what they perceived as blight and an unrelenting outflow of capital (Glass in Lees, Slater, Wyly 2010: 7; Teaford 1990: 231-252). Even when municipal governments attempted to capitalize on the quaintness of neighbourhood character to revitalize their cities, most attempts, as historian Jon Teaford has illustrated, failed. Neil Smith understood that banks and large private developers would not return their capital to the city until the "rent gap" was wide enough to assure satisfactory profit. Gentrification, to rephrase Smith's argument, occurred when urban spaces had been so sufficiently emptied of struggling residents and decaying properties that they could be "recycled" and begin "a new cycle of use" (Smith 1979: 545). For him, gentrification was not a story of consumption, but one of producing empty space and then filling it.

This was also his answer to those theorists of gentrification who believed consumers - usually, young, white professionals or artists who wished to reject the homogeneity of suburban life - were the shock-troops of gentrification. To him, they were more like the infantry set loose upon the battlefield after the bombs have already cleared the way. This is not to say their sense of taste and aesthetic preferences were not critical. For one thing, the basically sound (and attractive) buildings that stood or, in many cases, decayed upon land in the city's core, were often restored by these consumers. In his case study of Society Hill in Philadelphia, Smith identified the Old Philadelphia Development Corporation (OPDC), a private-sector, non-profit committee of banks, insurance companies, and the steel industry as a producer and marketer of emptied urban space (Smith 1979: 547). Its consumers, however, were those who were drawn to "restore their buildings to historic standards" with the assistance of the OPDC and Philadelphia Redevelopment Authority, which distributed "renovation guidelines" and 


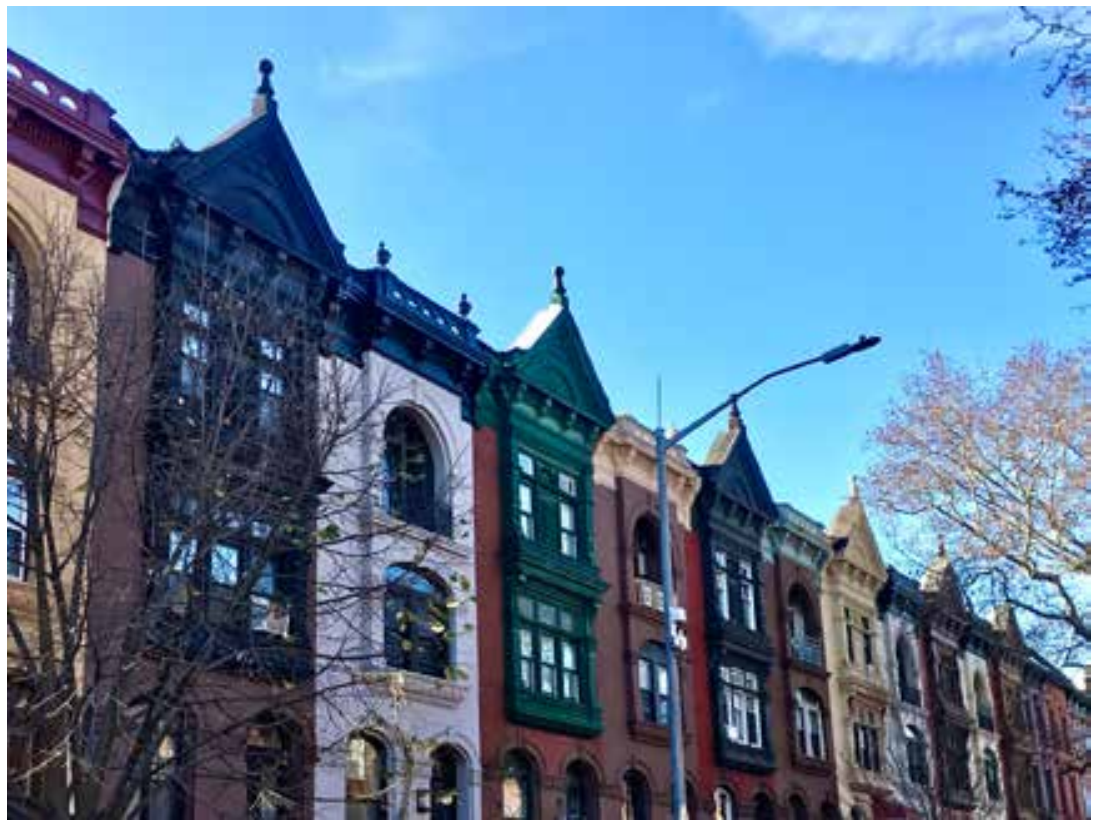

Figure 12.1: Brownstones. These row houses in Bedford-Stuyvesant, Brooklyn, feature parapets alternating with finial-topped gables. Brownstone Brooklyn neighbourhoods like this one attracted rehabbers as early as the 1960s. Photograph by Andre Carrotflower.

"salvaged a number of mantels, doors and windows" to freely distribute to rehabbers (Central Philadelphia Development Corporation: 3). At the same time, the restoration projects of Society Hill homeowners were not done simply for aesthetic purposes. "In the decision to rehabilitate an inner city structure," Smith wrote," the preference for profit, or, more accurately, a sound financial investment" is still more compelling than a polished-up facade (Smith 1979: 540).

The ordinary rehabbers of Smith's era - not just those in Philadelphia's Society Hill, but also the "brownstoners" of Brooklyn, the artists of Soho, the bohemians of Chicago's Lincoln Park - may have had utopian visions and aesthetic sentiments, but colonial and capitalist eyesight remained intact even for them. As historian Suleiman Osman has argued, some rehabber groups in Brooklyn in the 1970s formed block associations and worked with realtors to "attract new residents" to their "reawakening' neighborhood[s]" by inventing new, historically resonant neighbourhood names. The Boerum Hill Association, for example, invented the name "Boerum Hill" in the mid-196os, to reaffirm the area's presumed Dutch history and minimize the ubiquity of its contemporary, predominantly working-class, Latinx population. Realtors in a nearby Italian-American brownstone neighbourhood, 
which bordered the impoverished waterfront community of Red Hook, took Boerum Hill's cue by inventing its own name, Carroll Gardens, to firm up its association with green space and the American Revolution (Osman 2011: 198-201). Hundreds of miles west in Chicago, as Daniel Kay Hertz has explained, the rehabbers of Lincoln Park contended that the neighbourhood's "authentic" middle-class, Victorian-era charm would fall victim to neglect from its mostly poor white, Puerto Rican and Black residents without their social and cultural capital. They too believed they needed to market their "up and coming" neighbourhood to their peers because, as Hertz puts it, "Middle-class people would only purchase homes in places that they believed other middle-class people would purchase homes" (Hertz 2018: 58-59). Once the gentry was fully anchored in such communities, they also turned toward battling the interventions of local government to build affordable housing through urban renewal. In Brooklyn Heights, many homeowners who protested the construction of public housing through urban renewal planning dodged accusations of classism and racism by anchoring their critiques in aesthetic reasoning: "The solution to the problems of low-rent housing does not lie in the scaleless, intrusive, ill-designed brick monsters that we have come to know as the 'projects," wrote one local architect. Another resident proclaimed, "Brooklyn Heights has gained national attention by virtue of its remarkable degree of preservation ... Why, then, arbitrarily jeopardize an irreplaceable asset with an anomaly, when there are two hundred square miles of land area from which to select a much more suitable site for project housing" (Osman 2011: 156-157). These discourses of gentrification as aesthetic conservation or gentrification as the restoration of historical meaning saw little value in conserving or restoring existing populations. The filtering out of whole communities of working people was merely an unfortunate side effect of "reawakening neighborhoods." And for large-scale investors whose far-sighted manipulation of the land market already predicted increased "inner-city" valuation, displacement of the poor only further insured greater profit in the long run.

Half a century later, the gentrification recipe has not changed so much as matured. In Brooklyn Heights, skirmishes over the construction of affordable housing persist, although now the aesthetic issue brownstone homeowners have identified is the need to preserve waterfront views (Fishbein 2016). A neoliberal phalanx of city government and its planners, multinational banks, investment trusts, and wealthy consumers efficiently and relentlessly identify city spaces as underperforming, neglected, sparsely occupied, and ripe for reinvestment. Nowadays such spaces need not be abandoned to be perceived as empty, nor is their historical significance reason enough to 
"conserve" them. A single-family home in brownstone Brooklyn, a synagogue with low attendance, an urban farm, and an aging, low-rise commercial strip can all appear empty to agents seeking density and rapid return on investment. While banks, mortgage lenders, and realtors might have helped grease the wheels for individual rehabbers to pursue aesthetic preference in the past, today's neoliberal aesthetic is simply one of efficiency. If gentrification looked like a restored brownstone or an artists' loft in 1979, today it looks like a wall of partly vacant, prohibitively expensive, anonymous glass towers - little different from the "scaleless, intrusive, ill-designed brick monsters" of urban renewal, but connoting a far different class of occupant.

\section{Vacancy}

Like "filtering," the term "vacancy" has a particularly mercurial meaning in the current neoliberal context. A declaration of "vacancy" is also a powerful way to produce empty space in a jam-packed, growth-minded city. Vacancy has long provoked fear in the way "blight," "slum," and "inner-city" did in earlier times. Vacant property is an eyesore, public health hazard, financial liability, and inevitable sign of decline. It is viral, impossible to contain, an invitation to crime, a problem only entrepreneurial minds can solve. Fearful of all of these liabilities, local governments attempt to identify at-risk properties through a variety of methods. These include measuring census tract changes, searching tax liens, tracking foreclosures, monitoring neighbourhood complaints, and conducting visual surveys. Once properties have been targeted, municipalities spring into action, seeking innovative ways to fill the vacancies. In struggling cities such as Chicago, Newark, and Detroit, for example, the ubiquity of vacant lots and buildings has resulted in city programmes aimed at off-loading them to private owners. Chicago's "Large Lots" programme has so far sold 1,240 lots for \$1 each on its South and West Sides, while Newark's "Love Lots" programme resulted in the 14 February 2015 sale of 98 parcels for $\$ 1,000$ each to couples who promised to build housing on the site (Bonkamp 2018; Stillman 2016).

New York City, with its highest recorded population of 8.6 million people and almost legendary luxury construction boom is not immune to vacancy either, even in the midst of apparent plenty. The City's “Zombie Homes Initiative," launched in 2016, estimates between 2,000 and 4,000 vacant and abandoned homes in the five boroughs, while the city's general vacancy survey shows nearly 250,000 empty apartments in otherwise functioning buildings (Etherington 2008). Vacancy is not limited to residential properties. 


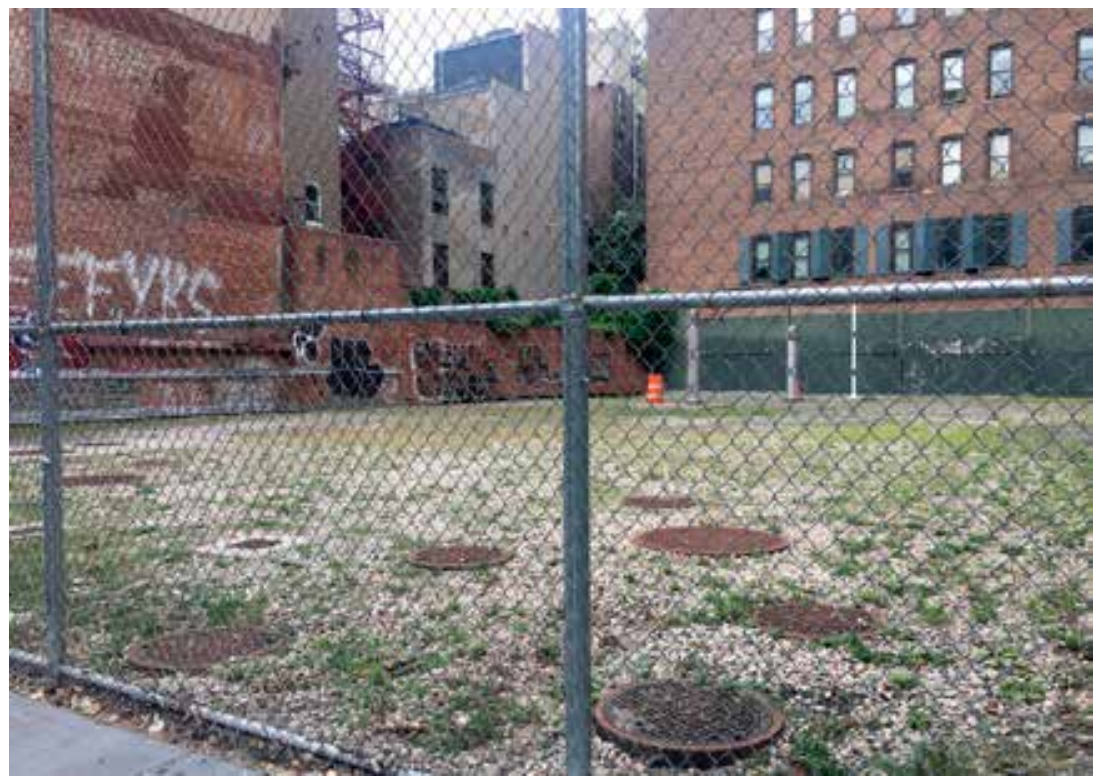

Figure 12.2: Vacant Lot, E. 4th Street Between Bowery and 2nd Avenue. Located next to New York's Merchant House Museum, this vacant lot at E. 4th Street between Bowery and Second Avenue is privately owned, but plans for developing it are unclear. The developer for the garage on the other side of the museum lost a legal battle to build an eight story hotel in 2018. Photograph by the author.

Recently, Manhattan Borough President Gale Brewer has co-sponsored a bill to require landlord registration of vacant and abandoned storefronts. Her concern is not limited to the mom-and-pop tailors and corner stores that New Yorkers of the Jane Jacobs generation praised for "taking care of the streets" (Jacobs 1992: 39). It is also for the designer shopping districts in the West Village and Soho - formerly neighbourhoods of incipient gentrification, now areas of "high-rent blight" - where emptiness belies the steady profits they still yield (Brewer 2019). The empty Marc Jacobs boutique on Bleecker Street does not present the same predicament as the overgrown urban prairie on Chicago's West Side, but both engender similar anxieties about vacancy as an early manifestation of decline.

But there are different kinds of empty space and different ways of seeing vacancy. Planning Scholars Karen Chapple and Miriam Zuk, who run the Urban Displacement Project at the University of California, Berkeley, have noted that, since vacancy is an umbrella term that describes a variety of urban spaces, it is nearly impossible to track. The aggregated data and visual observation collected by jittery local governments to pin down vacancies are not, as Chapple and Zuk explain, always comprehensive or 


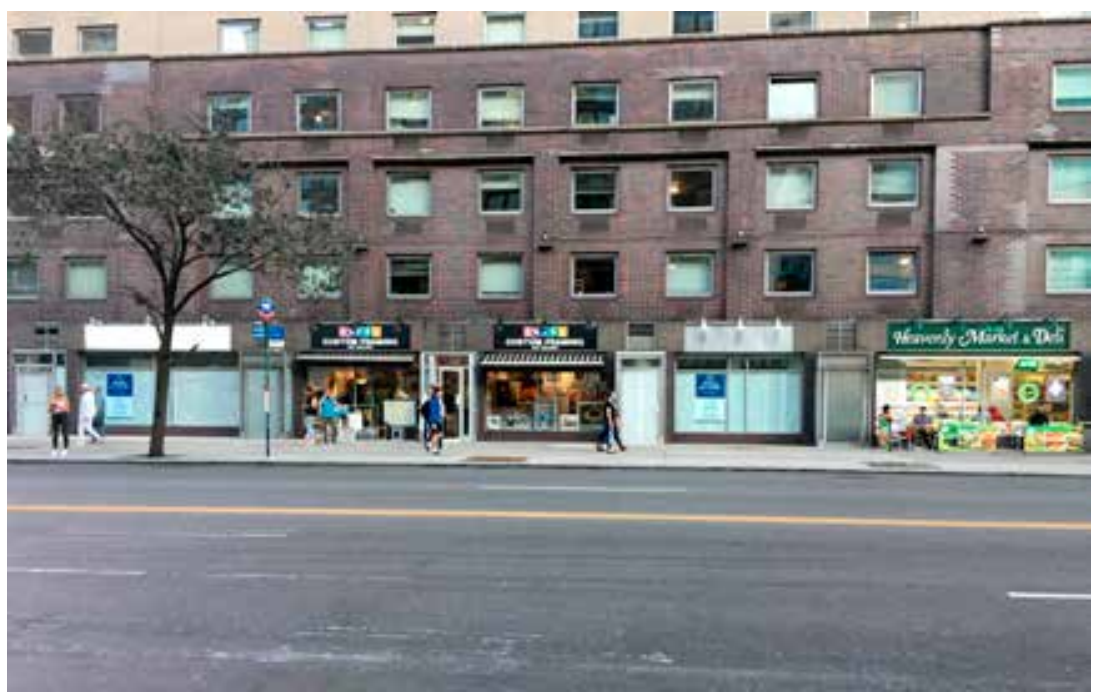

Figure 12.3: Vacant Storefronts, East Village. A thriving commercial strip fairly recently, this East Village thoroughfare has lost or flipped several small and medium-sized businesses in just the last two years. Photograph by the author.

accurate. In assessing the data-driven early warning systems that some non-profits, university think tanks, and cities have developed to assist with anti-displacement campaigns, Chapple and Zuk write of "the challenge of accounting for 'sites of reserve,' or property that landlords hold for decades in anticipation of future profit. As they lay fallow for decades, warning systems may suggest disinvestment, but locals know better" (Chapple and Zuk 2016: 126). Similarly, but for a different reason, the now-retired, New York City-based non-profit 596 Acres identified 1,018 publicly-owned lots that city documents recorded as "vacant," sometimes years after local residents had begun developing the lots as urban farms, gardens, open-air gallery spaces, playgrounds, and free parking lots. In other words, what aerial views and GIS maps - the harbour views of the twenty-first century - describe as "vacant" or empty space may be abundant when observed on the ground and over time.

A socially produced agreement that vacancy is an uncomplicated problem that needs immediate solution, usually through construction, is a prerequisite for neoliberalism to come to the rescue. Not only can private investors fill empty spaces with all manner of new development, they can mask one kind of vacancy with quite another. Manhattan's 432 Park Avenue, now the fifth tallest building in New York City, demonstrates how this is done. Constructed on the site of the former Art Deco-era luxury hotel The 
Drake, which was demolished for the purpose of redevelopment in 2007, $43^{2}$ Park Avenue is ninety-six stories in height and contains over 400,000 square feet of usable interior space. Carved out of that space are only 104 residential units, while the remainder of the building is intended to house retail, such as high-end perfumier Amaffi and Phillips Auction House. As Fortune magazine explained when the building was completed in 2014, "It is widely believed that the building will only be one-quarter occupied at all times, even though it will be completely sold out. Keep in mind that these are pied-a-terres that begin at $\$ 7$ million each and include several full-floor parcels in the $\$ 75$ million range" (Brown 2014). Five years later, this prediction of sizable vacancy coupled with soaring profits seemed to be accurate, so much so that the city attempted to pass a ridiculously modest pied-a-terre tax for second homes valued in excess of $\$ 5$ million. The legislation failed under mounting pressure from New York's real estate industry.

\section{Silence}

If neoliberalism warns that New York will meet certain death if it does not hock its empty spaces and public wares to the highest bidding developer, then those with a different urban imaginary - one that sees plenty where neoliberalism sees scarcity, community where GIS surveys see vacancy are ready for their moment of silence. Across New York City, community groups and like-minded friends are occupying spaces judged to be vacant and transforming them into resources available and accessible to all. They are taking the time to listen to their neighbours and deeply acknowledge the history beneath their feet, much as it seemed Dutch seafarer Jasper Danckaerts was poised to do in 1679 . Newcomers to the city in many cases, they are building utopias that do not depend on the destruction of what already exists. Rather, their objective is to bring what already exists back to life and fight for those people and places that gentrification seeks to displace.

Two of these efforts, CHARAS/El Bohio in Public School 64 on Manhattan's Lower East Side, which operated from 1977 to 2001, and the Smiling Hogshead Ranch, which was founded in 2011 and is still flourishing, demonstrate that community self-reliance, stewardship, and cooperation do have power in New York City. These sites, like the emerging community land trusts, cooperative groceries, and nascent New York City Real Estate Investment Cooperative, are idealistic in their dedication to re-commoning resources, but are not without precedent. As historian Joshua Freeman (2000) has explained, what many consider New York's mid-twentieth 
century golden age of social democracy depended on the cooperative traditions supported by the city's trade unions. There was a world before neoliberalism, and cooperative projects in New York today remind us there can be again.

CHARAS/El Bohio was officially established in Public School 64 in 1977. The name El Bohio, or "the hut" referenced the area's Puerto Rican roots, and CHARAS, the political and cultural organization that operated it, was eponymously named for its founders Chino Garcia, Angelo Rodriguez, Roy Batiste, Anthony Figueroa, and Sal Becker (Mottel 1973: 22). CHARAS pre-existed El Bohio and had emerged in the 1960 s as a counterpoint to Lyndon Johnson's War on Poverty, critiquing large-scale, top-down, state management of poverty relief (Vaughan 1967). By the late-1970s, when both federal and municipal governments had deserted the poor with the withdrawal of financing and a policy of "planned shrinkage," CHARAS used the opportunity to develop a system of community self-reliance and popular education. At the El Bohio school building, which the group was able to lease from the city in collaboration with the housing group Interfaith Adopt-a-Building, CHARAS supported occupation of the area's other abandoned buildings through tenant organizing, construction, conservation training, and cooperative neighbourhood planning. El Bohio's classrooms and auditorium hosted free and low-cost educational programmes in job training, theatre and musical performance, martial arts, dance, photography, film, and political organizing. Advancing the meaning of a public school, CHARAS opened its doors to anyone willing to teach and learn, all the while sprouting a network of local activists whose commitment to sustaining the neighbourhood's vitality stood in opposition to privatization.

For residents of the Lower East Side, or what many of the Puerto Rican, Spanish-speaking neighbourhood termed "Loisaida," community-determined activity at El Bohio not only built on their own collective resilience and promotion of local power through self-help and voluntarism. It was a direct and explicit critique of gentrification that drew from the anti-colonial discourse of the Puerto Rican independence movement. Indeed, poet and CHARAS activist Bimbo Rivas worried that "the colonial dependency state of mind" that had been foisted upon him and his Puerto Rican neighbours was "one of Loisaida's greatest enemies" (Rivas 1979). In contrast to the colonial view of empty spaces as potential private property, CHARAS and its allies advanced an interpretation of property as a common asset, aesthetically worthy because it fed everyone indiscriminately, a site of sufficiency rather than excess. This interpretation allowed for a counternarrative to the neoliberal definition of "equity" as one defined by the marketplace. From 


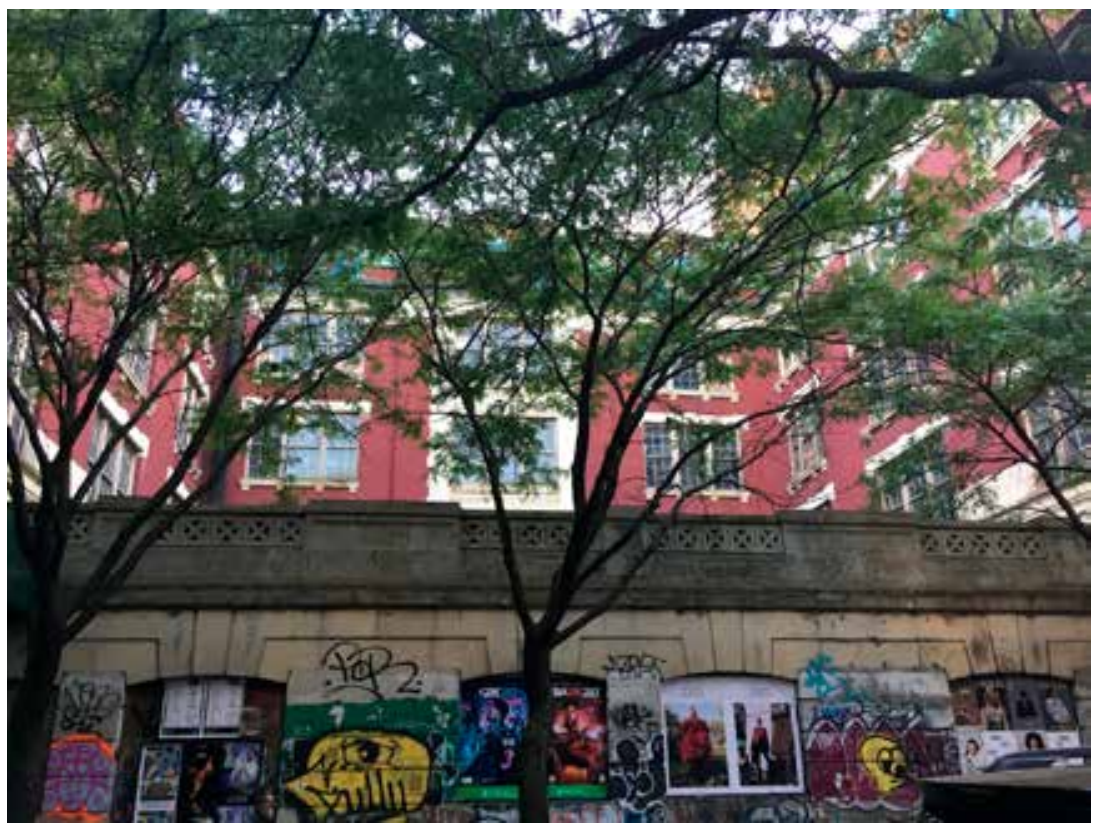

Figure 12.4: CHARAS/El Bohio. CHARAS/El Bohio was closed in 2001 and has remained empty and mostly unrepaired ever since. Speculator Gregg Singer, who purchased the property in 1998, stands to make back at least three times his investment when he sells. Photograph by the author.

CHARAS's perspective, equity was best understood by its other definition, “justice," and was produced by Lower East Side residents' investment of time and aesthetic imagination.

In the same decade that CHARAS/El Bohio was first occupied, garden activists the "Green Guerillas" were "seed bombing" neglected Lower East Side lots and developing community gardens with the help of their neighbours (Von Hassel 2005: 96). The city eventually acknowledged their work by formulating a registration process for gardening called the "Garden Lease" or "Garden License," that, as the city surmised, would appease locals while relieving it of maintenance responsibilities for abandoned property (Martinez 2010: 27). A similar short-term lease was what kept CHARAS in El Bohio for two decades. By 2011, Gil Lopez, a transplant from Florida who had spent much of his life gardening, also encountered the option to sign a garden license, this time with the Metropolitan Transit Authority. Lopez had expected to join a community garden as soon as he moved to the city, but found them frustratingly few and over-subscribed. With a background in landscape architecture and planning, he began to access city records to identify lots classified by the city of New York as vacant. His goal was to choose a site, test its soil to learn whether it was viable, and begin 


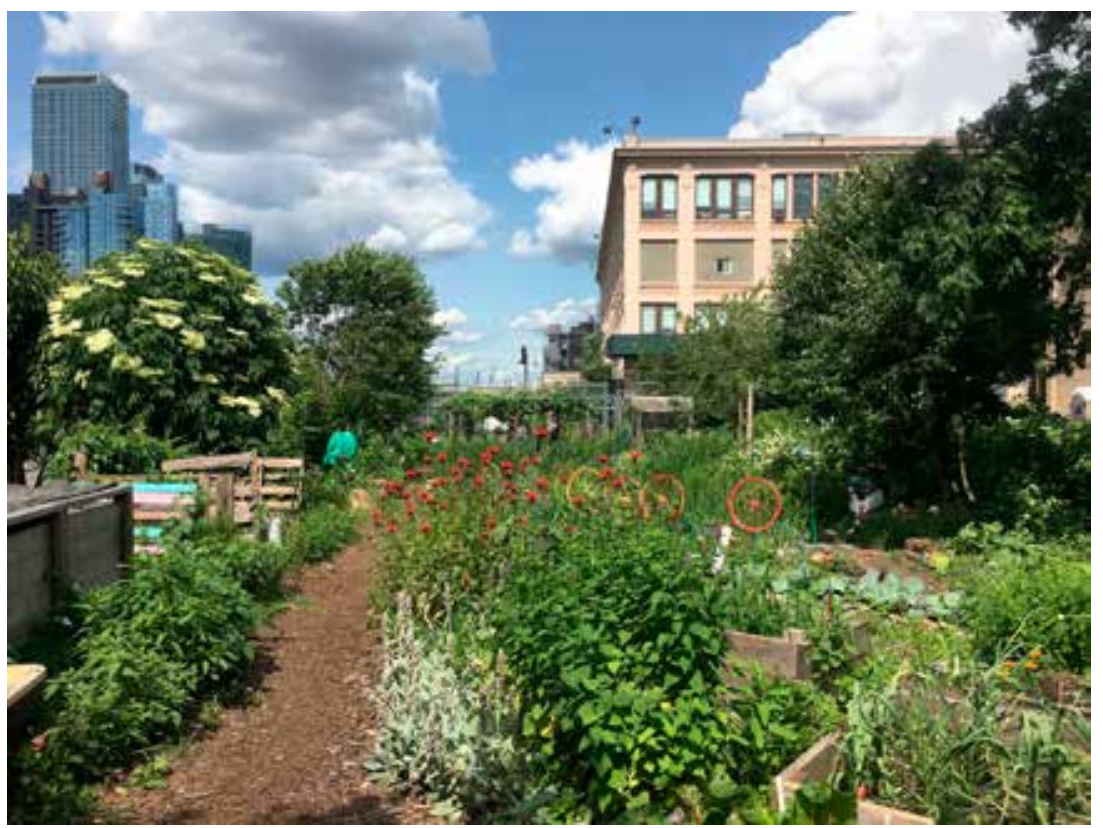

Figure 12.5: Smiling Hogshead Ranch, LIC behind. A view from inside Smiling Hogshead Ranch with new development in Long Island City in the background. The ranch faces potential eviction in the coming years as redevelopment of Sunnyside Yards right across the street gets underway. Photograph by the author.

planting row crops, fruit trees, and berry shrubs (Lopez 2019, interview with author). It became a site for gathering and contemplation where a spiritual connection to repairing the land was more valuable than planting the most obviously attractive flora. As he tells it, he understood his project as a form of direct action in service of growing food in a city with too few gardening opportunities. But, as he learned the history of the "Green Guerillas" and began working with a variety of activists, including Occupy Wall Street, he theorized his work as part of a continuum of practice that included renewing the land and advancing community control.

When Lopez, along with ten friends, started planting on the three-acre area located on the Montauk Cutoff of the Long Island Railroad in Long Island City and called it the Smiling Hogshead Ranch, they were making a claim to land in a city overdetermined by a particular kind of land value. They adopted an unofficial mission of community autonomy, respect for the land's history, care and repair, self-determination, and democratic participation in land use decisions. As Lopez, puts it, "For many communities, growing their own food is a direct response (or direct action) to counter the structural inequities built into policy decisions ... What we choose to do with 
the food we grow is not something the government gets to tell us" (Gil Lopez blog, https://verdantcities.wordpress.com). Yet, as Lopez soon learned, the government did have a stake in what the garden did. Signing a garden license, as the Ranch's directors were required to do in 2014, made it increasingly clear that, as Neil Smith discovered decades before, commodified land has value even if no one is using it.

\section{Pause}

The next chapters of the stories of CHARAS/El Bohio and Smiling Hogshead Ranch are predictable if one accepts a neoliberal logic. Because neoliberalism carries on the growth tradition of exploiting apparent problems like vacancy to create profit, it should come as no surprise that CHARAS/El Bohio was evicted by the city in 1998 so that real estate investor Gregg Singer could purchase and develop the building as-of-right for a then-outlandish $\$ 3.15$ million. Singer's plan was to use the city's "dormitory law" to gain a zoning variance that would allow him to increase his profit from the land sale (Anderson 2004). That never happened, but Singer can still expect to make a profit. The New York City Department of Finance has assessed the market value of the empty and deteriorating Public School 64 at $\$ 6.8$ million for 2019-2020, although a nearby vacant commercial triple-lot of comparable size sold in 2018 for $\$ 12$ million (New York City Department of Finance, Property Assessments 2019-2020). Singer could earn anything from double to quadruple his investment just by waiting. Meanwhile, Lopez and his collaborators at the Smiling Hogshead Ranch, who planted their crops more than a decade after CHARAS/El Bohio closed, are wary that the same could happen to them. In the decades since garden licenses were first offered, the city has cancelled them whenever it has been politically or economically profitable to do so. Lopez has argued that the Department of Housing Preservation and Development (HPD), which is responsible for the city's housing agenda, is too often "weaponized ... to issue injury to the community gardening movement” (Gil Lopez blog, https://verdantcities. wordpress.com). While this is true, the city hardly needs to use its housing agency to convince the Metropolitan Transit Authority to cancel its lease and sell off its parcels. Just across the street from Smiling Hogshead Ranch, the highly anticipated Sunnyside Yards development, which promises "world class institutions, major public space, jobs and affordable housing," is only months away from breaking ground (Murray 2019). True to New York's legacy of empire-building, the master planners of Sunnyside Yards, like those 
of Hudson Yards before it, cannot help but summon superlatives when it comes to a compelling opportunity to grow possible futures in a new land.

Even so, there are other ways to read these stories of resistance. While neoliberalism tells us, as Margaret Thatcher warned in the 1980 s, that "there is no alternative," community-based cooperative projects testify to the opposite. Moreover, they urge us not to believe that growth and creative destruction are the only ways to sustain New York's vitality. Indeed, it has been at moments of pause that the city has responded inclusively, graciously, and with inventiveness to the needs of the majority of New Yorkers. Rent regulation and public housing, for example, rose from the depths of tenant organizing and Communist party agitation during the Great Depression, while the city's Housing Development Fund Corporation cooperatives were established after the fiscal crisis of the 1970s. The credit union movement spread dramatically after World War II and cooperative grocery programmes prospered in Depression-era Harlem. One also cannot forget the care, mutuality, and shared hopes for recovery that came with the terrible silence and pause of September 11, 2001. The mounting waves of gentrification that followed that day can, in retrospect, buttress the argument that neoliberalism has prevailed. But that would deny the fortitude of activism that has since fought for - and won - stronger rent regulation protections, the nullification of Manhattan's Inwood rezoning (a model for others), and the swift withdrawal of plans for an Amazon headquarters in Long Island City, Queens. All of these victories can be read as demands for a pause in the growth machine.

This will be important to keep in mind as New York City's luxury real estate market begins to "soften," as economists put it, at an alarming rate. As Streeteasy.com reported in late-summer 2019, most new investors in the luxury market were renting their units in hopes that demand would pick up enough for them to reap a sizeable profit. At the same time, however, $25 \%$ of new condominiums constructed since 2013 remained unsold and more than sixty-three additional condominium buildings under construction in 2019 awaited sales (Long 2019). As the twenty-first century marches on, the city faces what Gothamist calls a "luxury glut" just as the Wall Street Journal reports that New York's population has begun to dip for the first time in a decade (Kim 2019; De Avila 2019). As in cities across the globe, cranes continue to perch atop rising buildings on New York's skyline even if no one quite knows who they are building for. Slow-downs at that level portend slow-downs deeper in the housing market as well.

Times like these insist that we reflect upon what growth can mean in a city when it is taken both more literally, as when Smiling Hogshead 


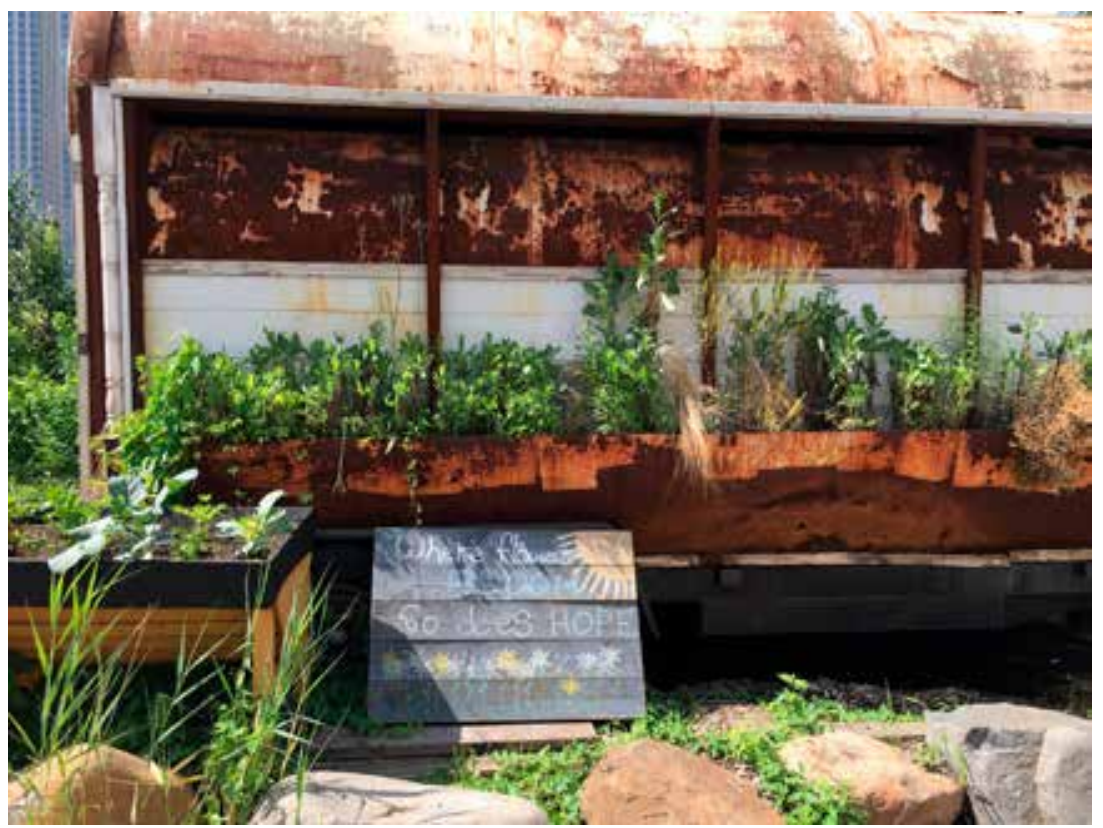

Figure 12.6: Smiling Hogshead Ranch, Where Flowers Bloom. At one of the entrances of Smiling Hogshead Ranch, a sign reminds visitors that "Where Flowers Bloom, So Does Hope." The ranch does not have fences or other clear boundaries as a statement against enclosure of private property. Photograph by the author.

Ranch advises that "where flowers bloom, so does hope," and with greater humanity. After all, newcomers to New York harbour were not wrong to see possible futures in a new land. They simply needed to recognize that other futures were already underway and that no land is ever new or empty. If we can learn to conserve more than parapet or a lead-lined stained-glass window as we build our cities of the future, we might just have a chance.

\section{Works Cited}

Anderson, Lincoln (2004) "Towering Dorm Is Proposed on the Former CHARAS Site." The Villager, 20 March (accessed 11 April 2019).

Bonkamp, Samantha (2018) "Chicago Selling 3,ooo-plus Properties Through $\$ 1$ Vacant Lot Program.” Chicago Tribune, 18 May (accessed 2 September 2019). Brewer, Gale (2019) "There Oughta Be a Law: We Need a Database to Track Vacant Storefronts." Retrieved from: https://www.manhattanbp.nyc.gov (accessed 11 April 2019). 
Brown, Joshua (2014) “Meet the House that Inequality Built: 432 Park Avenue." Fortune, 24 November (accessed 14 September 2019).

Caro, Robert A. (1974) The Power Broker: Robert Moses and the Fall of New York. New York: Knopf.

Central Philadelphia Development Corporation (2006) "OPDC/CPDC: 50 Years Remaking the Center City."

Chapple, Karen and Miriam Zuk (2016) "Forewarned: The Use of Neighborhood Early Warning Systems for Gentrification and Displacement." Cityscape 18.3: 109-130. Cinar, Alev and Thomas Bender (eds) (2007) Urban Imaginaries: Locating the Modern City. Minneapolis: University of Minnesota Press.

De Avila, Joseph (2019) “New York City's Population Dips for the First Time in Over a Decade." Wall Street Journal, 18 April (accessed 14 September 2019).

Danckaerts, Jasper (1913)Journal ofJasper Danckaerts, 1679-168o. C. Scribner's Sons. Etherington, Cait (2008) "NYC Zombie Houses: Why More Homes Are Vacant and Abandoned." 6sqft, 8 May (accessed 11 April 2019).

Fishbein, Rebecca (2016) “NIMBY's Get State to Block Affordable Housing at Brooklyn Bridge Park." Gothamist, 27 February (accessed 13 September 2019).

Fisher, Amber (2018) "City Sells Thousands of Vacant Lots for \$1 on South, West Sides." Patch, 18 May (accessed 9 April 2019).

Freeman, Joshua Benjamin (2000) Working-class New York: Life and Labor since World War II. New York: New Press.

Glanz, James and Eric Lipton (2003) City in the Sky: The Rise and Fall of the World Trade Center. New York: Macmillan.

Hertz, Daniel Kay (2018) The Battle ofLincoln Park: Urban Renewal and Gentrification in Chicago. Cleveland: Belt Publishing.

Jackson, Kenneth T. (2013) “Gotham's Towering Ambitions.” New York Times, 29 August. (accessed 14 September 2019).

Jacobs, Jane (1992) The Death and Life of Great American Cities. New York: Vintage Books.

Kim, Elizabeth (2019) "Report: NYC Has a Luxury Glut Problem." Gothamist, 13 September (accessed 14 September 2019).

Kraft, Herbert C. (1986) The Lenape: Archaeology, History, and Ethnography. Vol. 21. Newark: New Jersey Historical Society.

Lees, Loretta, Tom Slater and Elvin K. Wyly (2010) The Gentrification Reader. London: Routledge.

Long, Grant (2019) “NYC's Unsold Condos: Thousands of Units Linger on Market as More Are Built." One Block Over by Streeteasy, 13 September (accessed 14 September 2019).

Martinez, Miranda J. (2010) Power at the Roots Gentrification, Community Gardens, and the Puerto Ricans of the Lower East Side. Lanham, MD: Lexington Books. 
Molotch, Harvey (1976) "The City as a Growth Machine: Toward a Political Economy of Place." American Journal of Sociology 82.2: 309-332.

Mottel, Syeus (1973) Charas: The Improbable Dome Builders. New York: Drake Publishers, Inc.

Murray, Christian (2019) "City Presents Sunnyside Yards as An 'Enormous Opportunity', Many Remain Unconvinced." Sunnyside Post, 31 March (accessed 11 April 2019).

New-York Post (1853) New-York Post, 20 September 1853, quoted in Rosenzweig, Roy and Elizabeth Blackmar (1992) The Park and the People: a History of Central Park. Ithaca, N.Y.: Cornell University Press.

Osman, Suleiman (2011) The Invention of Brownstone Brooklyn: Gentrification and the Search for Authenticity in Postwar New York. Oxford: Oxford University Press.

Rivas, Bimbo (1979) “Loisaida: The Reality Stage.” WIN, 20 December.

Rosenzweig, Roy and Elizabeth Blackmar (1992) The Park and the People: a History of Central Park. Ithaca, N.Y.: Cornell University Press.

Smith, Neil (1979) "Toward a Theory of Gentrification A Back to the City Movement by Capital, not People." Journal of the American Planning Association, 45.4, 538-548.

Stillman, John (2016) “Why Hasn't Anyone Built on Newark's \$1,ooo Love Lots?” Urban Omnibus, 17 February [accessed 11 April 2019].

Teaford, Jon (1990) The Rough Road to Renaissance: Urban Revitalization in America, 1940-1985. Baltimore and London: The Johns Hopkins University Press.

Vaughan, Roger (1967) “The Real Great Society." Life, 15 September, 76.

Von Hassell, Malve (2005) "Community Gardens in New York City: Place, Community, and Individuality." Urban Place: Reconnecting with the Natural World, 91-116.

Whitman, Walt (2009) Leaves of Grass, 1860: The 15oth Anniversary Facsimile Edition. Iowa City: University of Iowa Press. ProQuest Ebook Central (accessed 16 September 2019).

Zukin, Sharon, Robert Baskerville, Miriam Greenberg, Courtney Guthreau, Jean Halley, Mark Halling, Kristin Lawler, et al. (1998) "From Coney Island to Las Vegas in the Urban Imaginary: Discursive Practices of Growth and Decline." Urban Affairs Review 33.5: 627-654.

\section{About the Author}

Rebecca Amato is a historian whose research and writing focus on the intersections between cities, space, place, and memory, with a special focus on the public humanities. Her work has appeared in the journals Urban 
Omnibus and Radical History Review, as well as More Art in the Public Eye (Duke, 2020) and A People's Guide to New York City (University of California, 2021). She has been a staff member and consultant at a variety of history institutions in New York, including the Brooklyn Historical Society, the American Social History Project, the Lower East Side Tenement Museum, and the Museum of the City of New York. She holds a PhD in United States History from The Graduate Center of the City University of New York. 
